() Орлова О.В., Животовська Л.В., Бойко Д.І., Боднар Л.А.

УДК 616.899-083-051-056.2

DOI https://doi.org/10.31718/mep.2021.25.5-6.04

\title{
ПОКАЗНИКИ ЯКОСТІ ЖИТТЯ ОСІБ, ЩО ДОГЛЯДАЮТЬ ЗА ПАЦІЄНТАМИ 3 ДЕМЕНЦІЄЮ
}

\author{
Орлова О.В., Животовська Л.В., Бойко Д.І., Боднар Л.А.
}

Полтавський державний медичний університет, м. Полтава,

Стаття є фрагментом науково-дослідної теми «Клініко-психопатологічні та параклінічні дослідження $і$ оптимізація лікувально-реабілітаційних заходів при основних формах психічної патології та коморбідних розладах» (№ державної реєстрації 0121U108235).

Dementia is associated with decreased memory, impaired thinking, behavior and ability to perform daily functions. This condition mainly affects the elderly and is one of the main causes of disability. Dementia affects not only patients, their families and caregivers, but society as a whole. The number of people with dementia is on the rise worldwide, and prognosis generally indicates a significant increase in overall prevalence associated with population aging. A large number of patients with dementia are at home, where their family members perform the function of caring for them. With the progression of the disease, patients lose the ability to care for themselves on their own, so the question of outside care arises for their relatives. The aim of this study is to analyze the quality of life indicators in persons performing the function of caring for patients with dementia. It has been found that almost $80 \%$ of patients with dementia are cared for by their relatives. Caregivers are at risk of depression, anxiety and psychological stress. In this study, the authors identified factors influencing the mental health of caregivers, among which the degree of dementia and the patient's ability to perform daily activities were significant. In caregivers with a low level of mental tension, manifestations of social maladaptation were less common. Depending on the level of psychological stress, individuals with a high level of tension had lower indicators of quality of life on the scales "physical functioning" $(p=0.003)$, "role functioning due to physical condition" $(p<0.001)$, "social functioning" $(p=0.04)$, "role functioning due to emotional state" $(p=0.003)$, "mental health" $(p=0,004)$. For this category of people, it is recommended to use counseling, psycho-educational activities aimed at understanding the improvement of quality of life.

Key words: caregivers of patients with dementia, quality of life, level of psychological stress.

Деменція супроводжується зниженням пам'яті, порушенням мислення, поведінки та здатності виконувати щоденні функції, що вражає здебільшого осіб літнього віку і $\epsilon$ однією з основних причин інвалідності. Це робить глибокий вплив не тільки на пацієнтів, їхні родини та осіб, які здійснюють догляд, а й на суспільство в цілому У всьому світі зростає кількість людей з деменцією і прогнози, як правило, свідчать про значне збільшення загальної поширеності, пов'язаної із старінням населення. Велика кількість пацієнтів з деменцією перебувають вдома, де функцію догляду за ними виконують рідні. При прогресуванні захворювання пацієнти втрачають можливість доглядати за собою самостійно, а тому перед рідними постає питання стороннього догляду. Метою роботи було провести аналіз показників якості життя осіб, що виконують функцію догляду за пацієнтами з деменцією. Встановлено, що майже за 80\% хворих на деменцію доглядають їхні родичі. Особи, які доглядають за пацієнтами, мають ризик депресії, тривоги та психологічного навантаження. В ході дослідження виявлено фактори, що впливають на психічне здоров'я доглядачів, серед яких вагомими були ступінь деменції та здатність пацієнта до повсякденної активності. У доглядачів із низьким рівнем показника психічної напруженості рідше відмічалися прояви соціальної дезадаптації. В залежності від рівня психологічного стресу, у осіб з високим рівнем психічної напруженості були нижчі показники якості життя за шкалами «фізичне функціонування» $(p=0,003)$, «рольове функціонування обумовлене фізичним станом» $(p<0,001)$, «соціальне функціонування» $(p=0,04)$, «рольове функціонування обумовлене емоційним станом» $(p=0,003)$, «психічне здоров я» $(p=0,004)$. Для даної категорії людей рекомендовано використовувати консультативну допомогу, психоосвітні заходи спрямовані на усвідомлення покращення якості життя.

Ключові слова: особи, що доглядають за пацієнтами із деменцією, якість життя, рівень психологічного стресу.

Деменція - синдром, який супроводжується зниженням пам'яті, порушенням мислення, поведінки та здатності виконувати щоденні функції, що вражає здебільшого осіб літнього віку і $є$ однією з основних причин інвалідності. Це робить глибокий вплив не тільки на пацієнтів, їхні родини та осіб, які здійснюють догляд, а й на суспільство в цілому [1]. Найбільш частою формою деменції $\epsilon$ хвороба Альцгеймера (60-80\%), рідше відмічається судинна (10-25\%), з тільцями Леві (7-25\%), змішані та інші не перевищують 10\% [2]. За даними Всесвітньої організації охорони здоров'я 2015 року кількість осіб, які страждають на деменцію, оцінювалася у 47,5 мільйонів осіб, до 2030 року передбачалося збільшення числа таких пацієнтів майже вдвічі (до 82 млн.), а до 2050 року до 152 мільйонів [3].

У зв'язку зі старінням населення, яке продовжує зростати та кількості людей, які живуть з хронічними захворюваннями, медична допомога все частіше переходить від лікарні до громади та сім'ї [4]. Велика кількість пацієнтів з деменцією перебувають вдома, де функцію догляду за ними виконують рідні. Через погану поінформованість та відсутність стратегії раннього виявлення когніти-

*Цитування при атестації кадрів: Орлова О.В., Животовська Л.В., Бойко Д.І., Боднар Л.А. Показники якості життя осіб, що доглядають за пацієнтами з деменцією // Проблеми екологї і медицини. - 2021. - T. 25, № 5-6. - С. 16-19. 
вних розладів у осіб похилого віку такі пацієнти не отримують лікування на ранніх етапах захворювання [5]. При прогресуванні захворювання вони втрачають можливість доглядати за собою самостійно, а тому перед рідними постає питання стороннього догляду [6].

Члени сім'ї $€$ ключовими для надання довготривалої допомоги пацієнтам, що значно збільшує ризик фізичного та емоційного навантаження [7]. Щоденна опіка вимагає максимального залучення особистісних адаптаційних процесів доглядачів і активізації психосоціального ресурсу в цілому, адже від допомоги доглядачів залежить ефективність лікування і якість життя хворих з деменцією $[8,9]$.

Метою роботи було провести аналіз показників якості життя осіб, що виконують функцію догляду за пацієнтами з деменцією.

\section{Матеріали та методи дослідження}

Із дотриманням принципів біоетики та медичної деонтології та за умови інформованої згоди обстежено 104 пацієнтів з деменцією та їх 104 доглядачі. Критеріями включення до участі в дослідженні осіб, що виконують функцію догляду були: інформована згода на проведення анкетування, клініко-психопатологічного та психодіагностичного обстеження, вік 25 років і старше, догляд за одним пацієнтом, у якого було діагностовано деменцію.

Дослідження проводилося 3 використанням психометричних шкал: опитувальника PSM-25 (в адаптації Н.Є. Водоп'янової, 2009) для оцінки показника психічної напруженості, шкали самооцінки соціальної адаптації SASS (Social Adaptation Self-evaluation Scale, 1997), анкети оцінки якості життя SF-36. Для пацієнтів з деменцією використовувалася коротка шкала оцінки психічного статусу (Mini-Mental State Examination, MMSE, 1975) для встановлення ступеню тяжкості деменції та шкала оцінки повсякденної активності (Weintraub et al., 2009).

\section{Результати та їх обговорення}

Доглядачі були розподілені на 3 групи в залежності від рівня психологічного стресу, який визначали за опитувальником PSM-25. В першу групу (Гр. І) було включено 33 (31,7\%) особи з низьким рівнем (до 100 балів) показника психічної напруженості (ППН), в другу групу (Гр. II) - 38 (36,5\%) з середнім рівнем ППН (100-154 балів), в третю групу (Гр. III) - 33 (31,7\%) з високим рівнем
ППН (більше 155 балів). Всі обстежені були репрезентативні за віком та статтю. В результаті опитування осіб, що доглядають за пацієнтами з деменцією, було виокремлено провідні скарги: дратівливість, відчуття відчаю і скорботи, почуття провини, самотності, виснаженості, втоми, відсутність часу для себе та інших членів родини. Ознаки психологічної напруженості вони описували у вигляді нездатності зосередитися, зниження уваги, труднощі у виконанні розумових операцій, зниження швидкості розумової переробки інформації.

Згідно короткої шкали оцінки психічного статусу (MMSE) легкий ступінь деменції мали $28(26,9 \%)$ пацієнтів, середній - 41 (39,4\%), тяжкий - 35 (33,7\%). Особи Гр. I доглядали за пацієнтами з деменцією, серед яких 14 (42,4\%) мали легкий ступінь, 16 (48,5\%) - середній, 3 $(9,1 \%)$ - тяжкий; в Гр. II - 10 (26,3\%), $15(39,5 \%), 13$ (32,4\%), в Гр. III - 4 (12,1\%), 10 (30,3\%) та 19 (57,6\%) відповідно. Легкий ступінь прогресування хвороби доглядачі описували як: «здатні обслуговувати себе самі, їм доступні звичні види побутової діяльності, такі як приготування їжі, прибирання, особиста гігієна», помірний «виникають труднощі з користуванням побутовою технікою, телефоном, людина забуває закривати двері, вимикати електрику і газ», важкий - «потребує цілодобового нагляду». При статистичному аналізі виявлено, що в Гр. I рідше відмічався тяжкий ступінь деменції на відміну від осіб з Гр. II ( $\left.x^{2}=3,841, p=0,012\right)$ та Гр. III ( $x 2=17,455$, $p<0,001)$.

Опитування за шкалою оцінки повсякденної активності показало, що серед всіх обстежених $50(48,1 \%)$ пацієнтів були здатні до виконання щоденних справ (до 8 балів), у 54 - (51,9\%) виникали труднощі при повсякденній активності (9-30 балів). Встановлено, що в Гр. I нормально справляються із повсякденними справами 32 $(97,0 \%)$ пацієнта 3 деменцією із середнім балом $6,88 \pm 0,14$, в Гр. II - $21(55,3 \%)$ з середнім балом $7,29 \pm 0,14$, а в Гр. III - 1 (3,0\%) з результатом 8,0 балів. Труднощі при виконанні щоденних справ відмічалися у 1 $(3,0 \%)$ пацієнта Гр. I з результатом 11 балів, у 17 (44,7\%) - Гр. II з середнім балом $12,06 \pm 0,56$ та у $32(97,0 \%)$ - Гр.

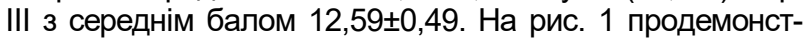
ровано результати, отримані за шкалою оцінки повсякденної активності.

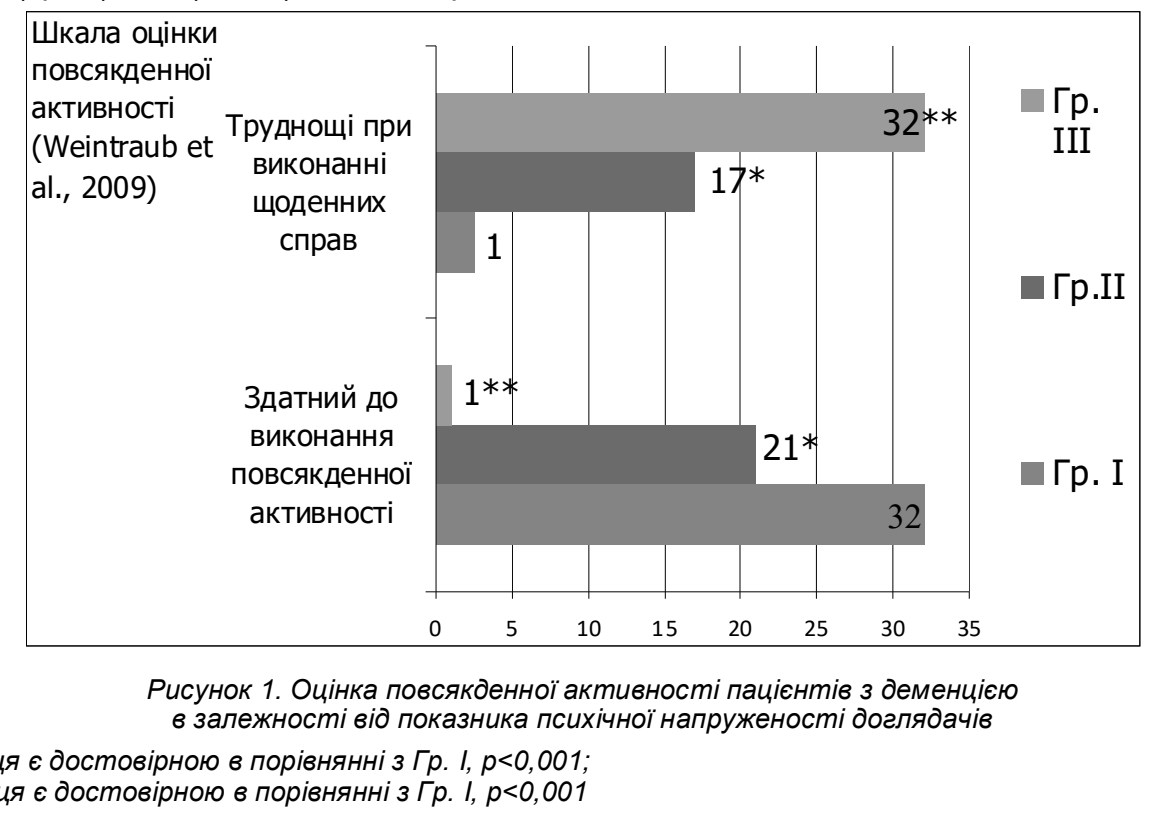


Спостерігалася значуща тенденція до зменшення частоти виникнення труднощів при повсякденній активності у пацієнтів з деменцією у Гр. I на відміну від осіб Гр. II (X2 =16,223, p<0,001) та Гр. III ( $\chi 2=58,242$, $p<0,001)$.

За результатами шкали SASS констатовано що у $33(31,7 \%)$ доглядачів відмічалась соціальна дезадаптація, у $29(27,9 \%)$ - ускладнена адаптація, у 29 $(27,9 \%)$ - достатній рівень адаптації та у $13(12,5 \%)-$ дуже добрий рівень адаптації. Результати оцінки со- ціальної адаптації за шкалою SASS продемонстровано в таблиці 1 . За такої умови в Гр. І 1 (3\%) особа мала соціальну дезадаптацію, 1 (3\%) - утруднену, 19 $(57,6 \%)$ - достатній рівень, $10(30,3 \%)$ - високий рівень соціальної адаптації. В Гр. II 7 (18,4\%) осіб мали дезадаптацію, 18 (47,4\%) - утруднену адаптацію, 10 $(26,3 \%)$ - достатній рівень, 3 (7,9\%) - високий рівень. В Гр. III дезадаптація була у 25 (75,8\%) доглядачів, утруднена адаптація - у 8 (24,2\%).

Таблиця 1. Оцінка соціальної адаптації в залежності від показника психологічної напруженості.

\begin{tabular}{|c|c|c|c|}
\hline Рівень соціальної адаптації & Група I & Група II \\
\hline Соціальна дезадаптація & $1(3 \%)$ & $7(18,4 \%)^{*}$ & $25(75,8 \%)^{\star *}$ \\
\hline Утруднена адаптація & $1(3 \%)^{*}$ & $18(47,4 \%)^{* *}$ & $8(24,2 \%)$ \\
\hline Достатній рівень адаптації & $19(57,6 \%)$ & $10(26,3 \%)$ & 0 \\
\hline Високий рівень адаптації & $10(30,3 \%)$ & $3(7,9 \%)$ & 0 \\
\hline
\end{tabular}

Примітка * різниця достовірна порівняно з Гр. І, p<0,01;

** різниця достовірна порівняно з Гр. $I, p<0,001$

При статистичному аналізі виявлено збільшення частоти проявів соціальної дезадаптації в Гр. III порівняно із Гр. II $(x 2=23,453, p<0,001)$ та Гр. I $(x 2=36,554, p<0,001)$. Утруднена адаптація частіше спостерігалася в Гр. II у порівнянні із Гр. I ( $(2=12,424, p<0,001)$, та в Гр. III у порівнянні із Гр. II ( $22=4,070$, p<0,044). Прояви дезадаптації проявлялися зміною поведінки доглядачів у соціальній сорері, її невідповідністю своїм соціальним функціям, психоемоційними порушеннями у вигляді негативно забарвлених переживань, іноді відмічалися клінічно виражені психопатологічні синдроми.

При оцінці якості життя за опитувальником SF-36 враховувалося зниження функціонування (менше 37 балів), що показано в таблиці 2. Виявлено, що в осіб Гр. I у порівнянні з Гр. II відмічалося зменшення частоти порушень фрізичного функціонування $(x 2=4,671$, $p=0,003)$, соціального функціонування $(x 2=4,24$, $p=0,04)$, психічного здоров'я $(x 2=7,889, p=0,05)$. В Гр. II порівняно з Гр. III констатовано збільшення частоти порушень фрізичного функціонування ( $x 2=6,424$, $p=0,012)$, життєвої активності $(x 2=13,255, p<0,001)$, соціального функціонування $(x 2=5,073, p=0,025)$, рольового функціонування, обумовленого емоційним станом $(X 2=9,031, \quad p=0,003)$, психічного здоров'я $\left(x^{2}=8,615, p=0,004\right)$.

Таблиця 2

\begin{tabular}{|c|c|c|c|}
\hline $\begin{array}{l}\text { Шкала оцінки } \\
\text { Показник психічної напруженості } \\
\text { якості життя SF-36 }\end{array}$ & $\begin{array}{l}\text { Гp. I } \\
\text { n (\%) }\end{array}$ & $\begin{array}{l}\Gamma \mathrm{p} . \mathrm{II} \\
\mathrm{n}(\%)\end{array}$ & 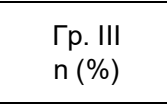 \\
\hline Фізичне функціонування & $0(0 \%)$ & $5(13,2 \%)^{*}$ & $13(39,4 \%)^{* *}$ \\
\hline $\begin{array}{l}\text { Рольове функціонування обумовлене фізичним } \\
\text { станом }\end{array}$ & $0(0 \%)$ & $4(10,5 \%)$ & $9(27,3 \%)^{*}$ \\
\hline Інтенсивність болю & $0(0 \%)$ & $1(2,6 \%)$ & $7(21,2 \%)^{*}$ \\
\hline Життєва активність & $4(12,1 \%)$ & $8(21,1 \%)$ & $21(63,6 \%)^{*}$ \\
\hline Соціальне функціонування & $5(15,2 \%)$ & $14(36,8 \%)^{*}$ & $21(63,6 \%)^{\star *}$ \\
\hline $\begin{array}{l}\text { Рольове функціонування обумовлене емоційним } \\
\text { станом }\end{array}$ & $10(30,3 \%)$ & $18(47,4 \%)$ & $27(81,8 \%)^{*}$ \\
\hline Психічне здоров`я & $9(27,3 \%)$ & $23(60,5 \%)^{*}$ & $30(90,9 \%)^{\star *}$ \\
\hline
\end{tabular}

Примітка: * різниця достовірна порівняно з Гр. I, p<0,01;

$$
\text { ** різничя достовірна порівняно з Гр. I, p<0,001 }
$$

При аналізі середніх показників за шкалами оцінки якості життя констатовано, що в Гр. І показник «фізичне фрункціонування» становив 52,91 1,55 балів, «рольове функціонування обумовлене фрізичним станом»

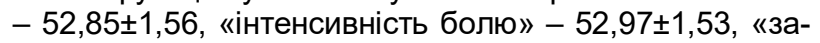

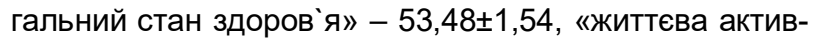
ність» - 50,76 $\pm 1,91$, «соціальне функціонування» $49,7 \pm 2,0$, «рольове функціонування обумовлене емоційним станом» - 47,73 $\pm 2,24$, «психічне здоров`я» $48,33 \pm 2,18$.

В Гр. II за шкалою «фізичне функціонування» середній бал був 45,53ะ1,49 балів, «рольове функціону-

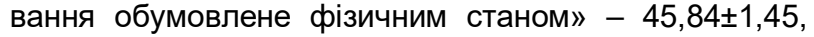

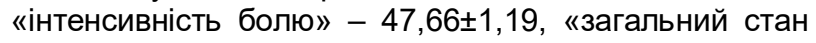

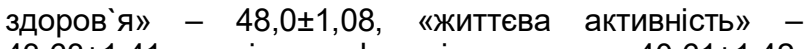
$43,63 \pm 1,41$, «соціальне функціонування» $-40,61 \pm 1,42$, «рольове фрункціонування обумовлене емоційним станом» - $38,63 \pm 1,48$, «психічне здоров'я» $36,53 \pm 1,4$.

В Гр. III показник «фрізичне функціонування» ста-

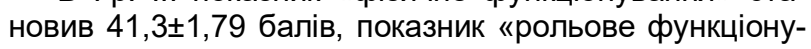

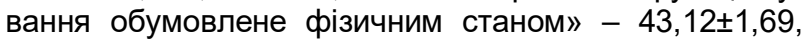

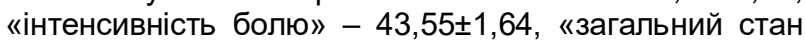

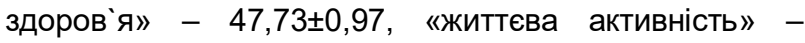
$38,3 \pm 1,82$, «соціальне фрункціонування» - 37,94 $\pm 1,72$, «рольове функціонування обумовлене емоційним станом» - $35,3 \pm 1,55$, «психічне здоров я» $32,88 \pm 1,03$, що зображено на рисунку 2. 


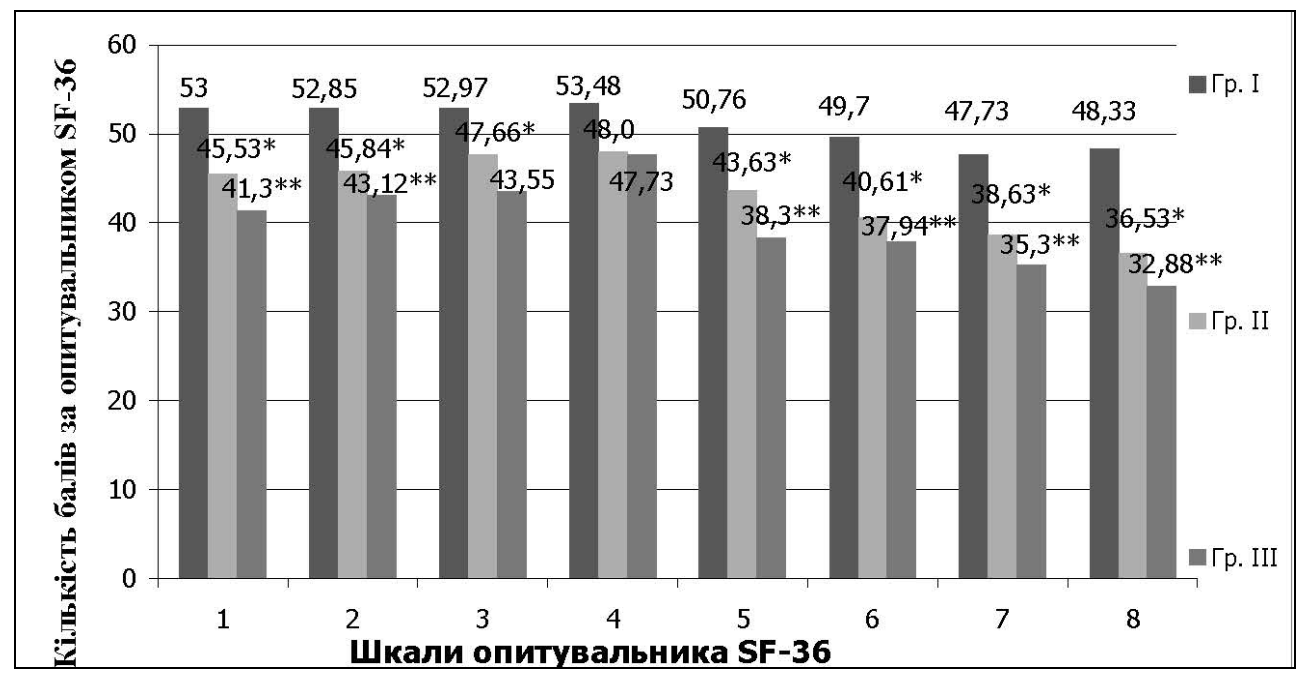

Рисунок 2. Характеристика досліджуваних за даними оцінки якості життя:

1 - фізичне функціонування, 2 - рольове функціонування обумовлене фрізичним станом, 3 - інтенсивність болю, 4 - загальний стан здоров я, 5 - життєва активність, 6 - соціальне функціонування,

7 - рольове фуннкиіонування обумовлене емоційним станом, 8 - психічне здоров я.

Середній бал за шкалами «фрізичне фрункціонування», «рольове функціонування обумовлене фрізичним станом», «рольове функціонування обумовлене емоційним станом» та «соціальне функціонування» в Гр. І був вище у порівнянні з Гр. II $(p<0,001)$ та Гр. III $(p<0,001)$. Статистично значуща різниця за показниками «інтенсивність болю» та «життєва активність» спостерігалася в Гр. I порівняно з Гр. II $($ p<0,001). За шкалою «психічне здоров я» показники були вище в Гр. I порівняно з Гр. II $(p<0,001)$ і Гр. III $(p<0,001)$ та в Гр. II порівняно з Гр. III $(p=0,03)$.

Таким чином, в ході дослідження виявлено фактори, що впливають на психічне здоров'я доглядачів, серед яких вагомими були ступінь деменції та здатність пацієнта до повсякденної активності. Встановлено, що у доглядачів із низьким рівнем показника психічної напруженості рідше відмічалися прояви соціальної дезадаптації ( $p<0,001)$. Констатовано, що в залежності від рівня психологічного стресу, у осіб з високим рівнем психічної напруженості були нижчі показники якості життя за шкалами «фізичне фрункціонування» $(p=0,003)$, «рольове функціонування обумовлене фрізичним станом» $(p<0,001)$, «соціальне функціонування» $(p=0,04)$, «рольове функціонування обумовлене емоційним станом» ( $p=0,003)$, «психічне здоров`я» $(p=0,004)$. Отримані дані свідчать про необхідність використання психоосвітніх заходів для доглядачів щодо їх власного здоров'я, визнання їх ключової ролі та пов'язаних з доглядом проблем, а також емоційну підтримку в ході консультування з питань їх установок і очікувань.

\section{Література}

1. Dementia: a public health priority. World Health Organization. $2012.112 \mathrm{~s}$.

2. Smolij G. Nastanovy shhodo vedennya paciyentiv iz demenciyeyu. 2019(1): 22-26

3. Collaborators GBDD. Global, regional, and national burden of Alzheimer's disease and other dementias, 19902016: a systematic analysis for the Global Burden of Disease Study 2016. Lancet Neurol. 2019;18:88-106.

4. Myshakivska OM. Svitova praktyka nadannia dopomohy khvorym na dementsiiu, paliatyvna dopomoha. Arkhiv psykhiatrii. 2013;19(4):42-43.

5. Isakov R.I. Analiz stavlennya do dostupnosti cinnostej riznih sfer zhyttiediialnosti u zhinok, hvorih na depresivni rozlad riznogo genezu, $v$ zalezhnosti vid virazhenosti psykhosotsialnoi dezadaptacii. Actual'nye problem transportnoj medytsyny. 2020; 1 (59): 36-44.

6. Mudrenko IH. Suchasni pohliady na sotsialno psykholohic hni, kliniko-psykhopatolohichni zakonomirnosti suitsydogenezu pry dementsiiakh ta metody sotsialnoi dopomohy. Psykhiatriia, nevrolohiia ta medychna psykholohiia. 2017;4(8): 33-39.

7. Korolyuk O. Profilaktika ta vedennya demenciï: zvit Komisiï Lancet (2020). Medichna gazeta «Zdorov'ya Ukraïni 21 storichchya». 2021;(1):496.

8. Gerasimenko L.O. psihosocial'na dezadaptaciya osib, yaki doglyadayut' pacientiv iz hvoroboyu Al'cgejmera. Medichna psihologiya, 2017; (1): 9-12.

9. Souza A. L. R., Guimaraes R. A., Vilela D., Factors associated with the burden of family caregivers of patients with mental disorders: a crosssectional study. BMC Psychiatry. 2017; 17(1). P. 353. DOI : 10.1186/s12888-017-1501-1.

Матеріал надійшов до редакції 01.11.2021. 